\title{
Apedunculata discoidea gen. n., sp. n. (Monogenea: Dactylogyridae) parasitic on Prochilodus lineatus (Valenciennes, 1837) (Characiformes: Prochilodontidae) from southeastern Brazil
}

\author{
Cuglianna, AM. ${ }^{\mathrm{a}}$, Cordeiro, NS. a and Luque, JL. ${ }^{\mathrm{b} *}$

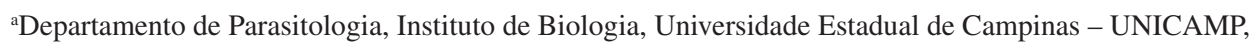 \\ CP 6109, CEP 13083-970, Campinas, SP, Brazil \\ bepartamento de Parasitologia Animal, Universidade Federal Rural do Rio de Janeiro UFRJ, \\ CP 74508, CEP 23851-970, Seropédica, RJ, Brazil \\ *e-mail: jlluque@ufrrj.br \\ Received November 16, 2007 - Accepted December 12, 2007 - Distributed August 31, 2009
}

(With 7 figures)

\begin{abstract}
A new species of dactylogyrid monogenean, Apedunculata discoidea gen. n., sp. n. is described and illustrated from the gills of the freshwater fish Prochilodus lineatus (Valenciennes, 1837) in pisciculture ponds from Pirassununga, São Paulo, Brazil. Diagnostic characters of the new genus and species are: 1) vagina dextrolateral slightly sclerotised, opening anteriorly at level of copulatory complex; 2) copulatory organ coiled with two counterclockwise rings; 3) Accessory piece distal and not articulated; 4) body disk-shaped, lacking a peduncle.
\end{abstract}

Keywords: Monogenea, Dactylogyridae, Apedunculata discoidea gen. n., sp. n., Prochilodus lineatus, Prochilodontidae.

\section{Apeduncullata discoidea gen. n., sp. n. (Monogenea: Dactylogyridae) parasito de Prochilodus lineatus (Valenciennes, 1837) (Characiformes: Prochilodontidae) do sudeste do Brasil}

\section{Resumo}

Uma espécie nova de monogenético dactilogirídeo, Apedunculata discoidea gen. n., sp. n. parasita das brânquias do peixe de água doce Prochilodus lineatus (Valenciennes, 1837) proveniente de pisciculturas de Pirassununga, São Paulo, Brasil, é descrita e ilustrada. As características diagnósticas do novo gênero e da nova espécie são: 1) vagina dextrolateral levemente esclerotizada, com abertura ao nível do complexo copulatório; 2) órgão copulatório em espiral com duas voltas no sentido anti-horário; 3 ) peça acessória distal e não articulada; 4) corpo com formato de disco e sem pedúnculo.

Palavras-chave: Monogenea, Dactylogyridae, Apedunculata discoidea gen. n., sp. n., Prochilodus lineatus, Prochilodontidae.

\section{Introduction}

Prochilodontids are benthopelagic, potamodromous fishes with significant importance as food resource and they have great potential for intensive pisciculture. Nevertheless, there are only a few studies on monogeneans parasitic on these species from Brazil. Rhinonastes pseudocapsaloideum Kritsky, Thatcher and Boeger, 1988 parasitic on P. nigricans Agassiz; Tereancistrum ornatus Kritsky, Thatcher and Kayton, 1980 and Anacanthoroides mizellei Kritsky and Thatcher, 1976 parasitic on $P$. reticulatus Steindachner, were described from the Amazonas River Basin (Kritsky and Thatcher, 1976; Kritsky et al., 1980; 1988). Eiras et al. (1995) re- corded unidentified dactylogyrids from the gills and skin of $P$. lineatus from ponds in São Paulo. Most recently, three species of monogeneans parasitizing $P$. lineatus Valenciennes from Paraná and Paranapanema Rivers were described, respectively: Kritskyia boegeri Takemoto, Lizama and Pavanelli, 2002, Protorhinoxenus prochilodi Domingues and Boeger, 2002, Tereancistrum curimba Lizama, Takemoto and Pavanelli, 2004, T. ornatus Lizama, Takemoto and Pavanelli, 2004 and Rhinoxenus curimbatae Domingues and Boeger, 2005 (Domingues and Boeger, 2002; 2005; Takemoto et al., 2002; Lizama et al., 2004).

In this report, a new genus of dactylogyrid is proposed and a new species parasitic on Prochilodus 
lineatus (Valenciennes, 1837) from Brazil is described and illustrated.

\section{Material and Methods}

The monogeneans studied are part of the material collected from 72 specimens of $P$. lineatus collected from pisciculture ponds of CEPTA (Centro de Pesquisa e Gestão de Recursos Pesqueiros Continentais) in Pirassununga, state of São Paulo, Brazil, from April 1999 to March 2000. The fish measured $24-33 \mathrm{~cm}($ mean $=27 \pm 2.9 \mathrm{~cm})$ in standard length and weighed 321-512 $\mathrm{g}$ (mean $=406.2 \pm$ $61.7 \mathrm{~g}$ ). The monogeneans were removed from the gills of the hosts with a 1:4000 formalin solution, fixed in 5\% formalin and stored in $70 \%$ ethanol. Additional collections of monogeneans were made using hot water followed by immediate fixation in 5\% formalin. The parasites were stained with Gomori's trichrome and mounted in Canada balsam; some specimens were mounted in Gray and Wess medium (Humason 1979) for study of sclerotised structures. Measurements are in micrometres $(\mu \mathrm{m})$, the mean is followed by the range and number of specimens measured (n) in parentheses. The illustrations were made with the aid of a drawing tube mounted on a Hund Wetzlar H-600 phase contrast microscope. The holotype and the paratypes were deposited in the Helminthological Collection of the Instituto Oswaldo Cruz (CHIOC), Rio de Janeiro, Brazil.

\section{Results}

\section{Monogenea Van Beneden, 1858}

\section{Dactylogyridae Bychowsky, 1933}

\section{Apedunculata gen. $\mathrm{n}$.}

Diagnosis: Body disk-shape, divided into cephalic region, trunk, haptor. Tegument thin. Eyes 4. Pharynx muscular, glandular; intestinal caeca 2, confluent in posterior trunk, lacking diverticula. Gonads overlapping, testis dorsal to germarium. Vas deferens apparently looping left caecum, seminal vesicle a dilatation of vas deferens; prostatic reservoir at level of anterior portion of caeca. Copulatory complex comprising sclerotised male copulatory organ, accessory piece. Male copulatory organ a coiled sclerotised tube with counterclockwise rings. Accessory piece not articulated. Seminal receptacle anterior to testis. Vagina sclerotised; vaginal aperture sligthly sclerotised, dextrolateral. Vitellaria follicular. Haptor with 14 hooks with typical ancyrocephaline distribution (Mizelle 1936), comprising shank of two subunits; ventral bar "U-modified" shape; dorsal bar elongate; pair of ventral and dorsal anchors with shaft and base differentiated, deep roots. Parasites of gills of characiform fishes.

Etymology: the generic name refers to absence of haptor peduncle. Latin (a [absence] + pedunculus [ peduncle]).

Type-species: Apedunculata discoidea sp. n. parasitic on Prochilodus lineatus (Valenciennes, 1837) (Characiformes, Prochilodontidae).

\section{Apedunculata discoidea sp. n. (Figs. 1-7)}

Description: (based on 25 specimens): Body diskshape, $280(220-410, \mathrm{n}=25)$ long, greatest width 160 $(110-260, n=25)$. Cephalic lobes scarcely developed; cephalic glands. Posterior pair of eyes greater than anterior pair. Few accessory granules dispersed in anterior body. Pharynx spherical, $25(22-33, \mathrm{n}=9)$ in diameter. Peduncle absent. Haptor $12(11-13, \mathrm{n}=5)$ long, 136 $(110-180, \mathrm{n}=11)$ wide. Ventral anchor, short broad deep root, curved shaft, recurved point extending to root level,16 (13-18, $\mathrm{n}=10)$ long, $13(10-15, \mathrm{n}=10)$ wide; dorsal anchor similar but with elongated deep root, 20 $(13-23, \mathrm{n}=10)$ long, $16(13-23, \mathrm{n}=10)$ wide. Ventral bar 35 (31-46, $\mathrm{n}=12)$ long, U-shape; dorsal bar 42 (31-52, $\mathrm{n}=14$ ) long, longer than ventral bar, with medial ondulation. Hooks similar, $6.5(5.0-10.0, \mathrm{n}=6)$ long, posterior shank subunit wider than anterior subunit, truncated thumb, evenly curved shaft and point; FH loop extending to end of anterior shank subunit. Male copulatory organ sclerotised, a coiled tube with two counterclockwise rings, proximal ring $32(26-41, \mathrm{n}=10)$ in diameter. Accessory piece not articulated, without copulatory ligament. Testis dorsal to germarium, spherical, 42 (31-65, $\mathrm{n}=11$ ) in diameter; vas deferens elongate; conspicuous seminal vesicle; prostatic reservoir at level of anterior portion of caeca. Germarium pyriform $53(39-70, n=4)$ long, 22 (20-26, $\mathrm{n}=4)$ wide; dextrolateral vaginal duct slightly sclerotised, $86(60-120, n=12)$ long, opening into central seminal receptacle. Vitellaria lateral. Uterus not observed.

Type-host: Prochilodus lineatus (Valenciennes, 1837)

Site of infection: gills.

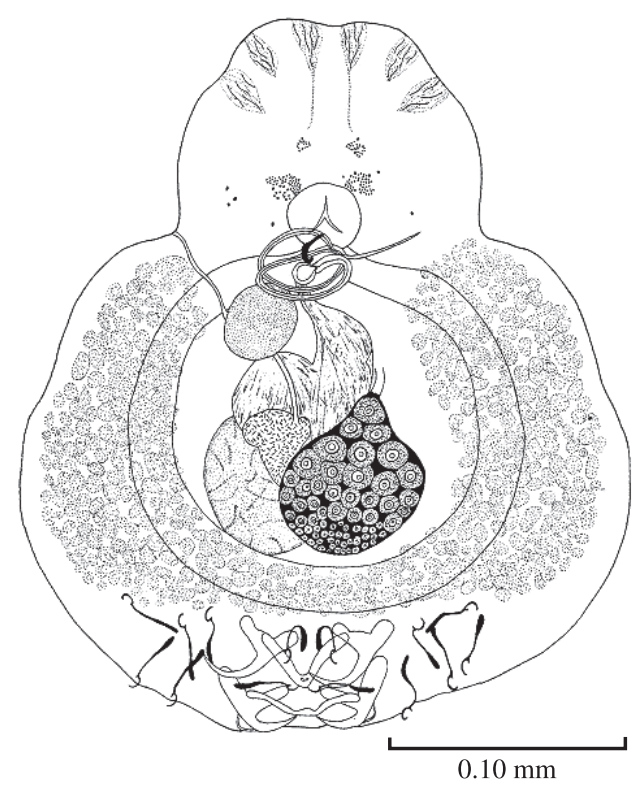

Figure 1. Apedunculata discoidea gen. n., sp. n. Composite drawing of whole mount (ventral view). 
Type-locality: ponds in Pirassununga, State of São Paulo, Brazil.

Type-specimens: holotype, CHIOC No 36904, paratypes (four specimens stained and mounted) CHIOC No 36905 to 36908.

Etymology: the specific name refers to the disk shape of the body.

\section{Discussion}

Apedunculata discoidea gen. n., sp. n. can be defined by a combination of characters: 1) vagina dextrolateral slightly sclerotised, anteriorly opening at level of copulatory complex; 2) copulatory organ coiled with two counterclockwise rings; 3 ) accessory piece distal and not articulated; 4) body disk-shape with absence of haptor peduncle. The new genus is close to Demidospermus Suriano, 1983 by the presence of vaginal aperture to the level of copulatory complex and by the presence of accessory piece of male copulatory complex not articulated (see Kritsky and Gutierrez, 1998), nevertheless, the new genus can be separated from Demidospermus by the absence of haptorial peduncle, testis dorsolateral to germarium (postgermarial in Demidospermus), number of rings of the copulatory organ (a single ring in
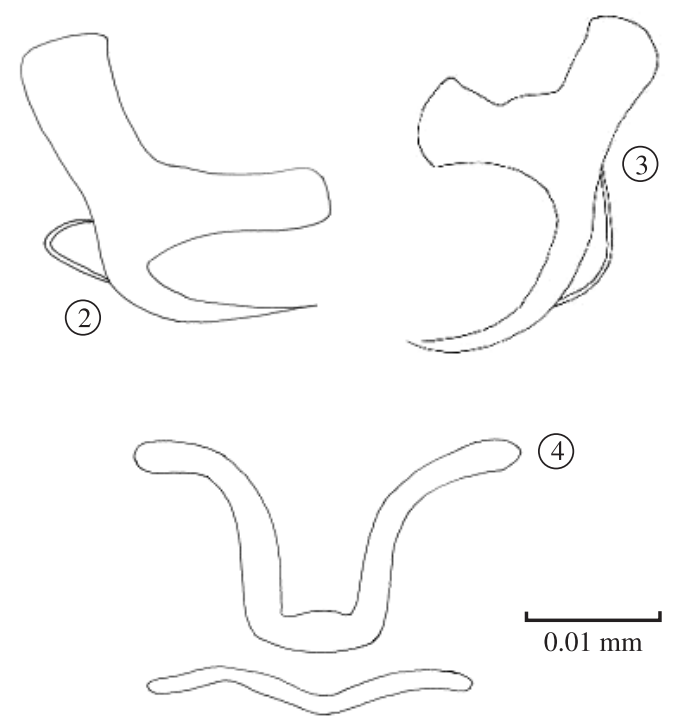

(5)
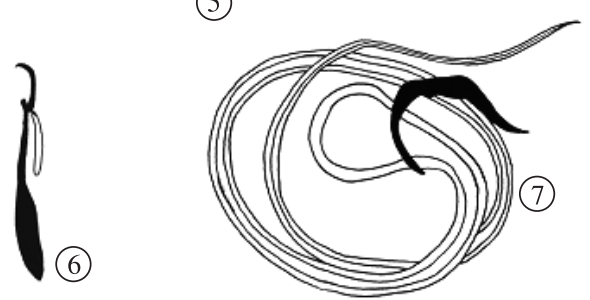

Figures 2-7. Apedunculata discoidea gen. n., sp. n. Figure 2. Dorsal anchor. Figure 3. Ventral anchor. Figure 4. Ventral bar. Figura 5. Dorsal bar. Figure 6. Hook. Figure 7. Male copulatory organ (dorsal view).
Demidospermus) and by the vaginal aperture (sinistrolateral in Demidospermus).

Gussevia Kohn and Paperna, 1964 is another dactylogyrid genus close to Apedunculata gen. n. because the presence of dextrolateral vagina and accessory piece not articulated (see Kritsky et al., 1986), but can be easily separated from the new genus by the cirrus coil (with clockwise rings in Gussevia; with counterclockwise rings in the new genus) and the configuration of the haptor (divided in anterior and posterior lobes in Gussevia; not divided in Apedunculata gen. n.). Also, all known species of Gussevia are parasitic on cichlid fishes, while the type species of the new genus is parasite of a prochilodontid fish.

Acknowledgements - We thank Paulo S. Ceccarelli (CEPTA) for providing the fishes studied. Ana M. Cuglianna was partially supported by a student fellowship from the Coordenação de Aperfeiçoamento do Pessoal do Ensino Superior (CAPES). José L. Luque was supported by a Research fellowship from CNPq (Conselho Nacional de Pesquisa e Desenvolvimento Tecnológico).

\section{References}

DOMINGUES, MV. and BOEGER, WA, 2002. Neotropical Monogenoidea. 40. Protorhinoxenus prochilodi gen. nov., sp. nov. (Monogenoidea: Ancyrocephalinae), parasite of Prochilodus lineatus (Characiformes:Prochilodontidae) from South Brazil. Folia Parasitologica, vol. 49, no. 1, p. 35-38.

2005. Neotropical Monogenoidea. 47. Phylogeny and coevolution of species of Rhinoxenus (Monogenoidea, Ancyrocephalinae) and their Characiformes hosts (Teleostei, Ostariophysi) with description of four new species. Zoosystema, vol. 27 , no. 3, p. 441-467.

EIRAS, JC., RANZANI-PAIVA, MJT., ISHIKAWA, CM., ALEXANDRINO, AC. and EIRAS, AC., 1995. Ectoparasites of semi-intensively farmed tropical freshwater fish Piaractus mesopotamicus, Prochilodus lineatus and Colossoma macropomum in Brazil. Bulletin of European Association of Fish Pathologists, vol. 15, no. 5, p. 148-151.

HUMASON, GL., 1979. Animal tissue techniques. EUA: W. H. Freeman Co. 661 p.

KRITSKY, DC. and THATCHER, VE., 1976. New Monogenetic Trematodes from freshwater fishes of Western Colombia with the proposal of Anacanthoroides gen. n. (Dactylogyridae). Proceedings of the Helminthological Society of Washington, vol. 43, no. 2, p. 129-134.

KRITSKY, DC. and GUTIERREZ, PA., 1998. Neotropical Monogenoidea. 34. Species of Demidospermus (Dactylogyridae, Ancyrocephalinae) from the gills of Pimelodids (Teleostei, Siluriformes) in Argentina. Journal of Helminthological Society of Washington, vol. 65, no. 2, p. 147-159.

KRITSKY, DC., THATCHER, VE. and KAYTON, RJ. 1980. Neotropical Monogenoidea. 3. Five new species from South America with the proposal of Tereancistrum gen. n. and Trinibaculum gen. n. (Dactylogyridae: Ancyrocephalinae). Acta Amazonica, vol. 10, no. 2, p. 411-417.

KRITSKY, DC., THATCHER, VE. and BOEGER, WA., 1986. Neotropical Monogenea. 8. Revision of Urocleidoides (Dactylogyridae, Ancyrocephalinae). Proceedings of the 
Helminthological Society of Washington, vol. 53, no. 1, p. 1-37.

KRITSKY, DC., THATCHER, VE. and BOEGER, WA., 1988. Neotropical Monogenea. 13. Rhinonastes pseudocapsaloideum n. gen., n. sp. (Dactylogyridae, Ancyrocephalinae), a nasal parasite of curimatá, Prochilodus nigricans Agassiz (Cypriniformes, Prochilodontidae), in Brazil. Journal of Parasitology, vol. 74, no. 4, p. 695-698.

LIZAMA, M. de los AP, TAKEMOTO, RM. and PAVANELLI, GC., 2004. New species of Tereancistrum Kristsky, Thatcher and Kayton, 1980 (Monogenea: Dactylogyridae: Ancyrocephalinae) from the gills of Prochilodus lineatus (Osteichthyes: Prochilodontidae) from the upper Paraná River floodplain, Brazil. Systematic Parasitology, vol. 57, no. 1, p. 45-49.

MIZELLE, JD., 1936. New species of trematodes from the gills of Illinois fishes. American Midland Naturalist, vol. 17, no. 5, p. $785-806$.

TAKEMOTO, RM., LIZAMA, MA. And PAVANELLI, GC., 2002. A new species of Kritskyia (Dactylogyridae, Ancyrocephalinae) parasite of urinary bladder of Prochilodus lineatus (Prochilodontidae, Characiformes), from the floodplain of the high Paraná River, Brazil. Memórias do Instituto Oswaldo Cruz, vol. 97, no. 3, p. 313-315. 